\title{
Are treasury debt instruments still attractive to foreign investors? Poland - a case study based on ATM and ATR indicators
}

Agnieszka Kłysik-Uryszek*

Tomasz Uryszek**

\section{Introduction}

Growing volumes of public debt have been one of the characteristics of most free-market economies, including Poland. Financing investments, as well as current consumption with public borrowing, seem very attractive to governments. On the other hand, public authorities cannot use ever-increasing debt (see, e.g., Martins-da-Rocha, Vailakis 2012; Minea, Villieu 2010; Wigger 2009).

Public debt instruments used to be treated as "risk-free" papers, and the last financial crisis verified this perception. The risk premium went up, making the cost of debt service higher. We should remember that lowering debt service costs is the essential aim of a public debt management strategy. In recent years, according to the debt management strategy in Poland (Strategia... 2018, pp. 9-15), this aim should be achieved by:

- maintaining the flexibility of the financing structure in terms of market, currency, and instrument choice;

- increasing the share of the domestic instruments;

- decreasing the share of foreign currency-denominated securities;

- maintaining the average time to maturity of public debt at about 5-years (which is a shorter term than the initial average term to maturity of instruments directed to foreign investors).

* Agnieszka Kłysik-Uryszek - Ph.D., University of Łódź, Faculty of Economics and Sociology, Department of International Trade, agnieszka.klysik@uni.lodz.pl

** Tomasz Uryszek - Ph.D., University of Łódź, Faculty of Economics and Sociology, Department of Banking, tomasz.uryszek@uni.lodz.pl 
In such circumstances, the following question arose: are international investors still interested in buying sovereign debt instruments? Thus, the article investigates foreign investors' activity on the Polish, primary market of public debt instruments.

\section{Literature review}

Investors can be divided into different categories, depending on the study's purpose, e.g., individual and institutional, or domestic and foreign. Foreign investors play an important role in maintaining the financial balance of the economy. Due to foreign capital inflow, it is possible to finance many important areas of the economy. Foreign investors may act as direct investors and portfolio investors (see, e.g., Ahlquist 2006; Hayat 2019), and their investment motives differ (see, e.g., Ho, Atkinson 2018; Bitzenis, Žugić 2014; Garg, Dua 2014). In this article, we are especially interested in institutional foreign portfolio investors who buy Treasury debt securities to invest their financial resources at the lowest possible risk and - in this way - diminish the level of their total portfolios' investment risk (Matsumura, Kakinoki 2014)

On the other hand, governments (fiscal agents) seek to borrow money at the lowest possible cost. At the same time, they have to control and - if possible - diminish the levels of refinancing, the interest rate, and currency risks (Cazac 2018; Grundke 2004; Capasso, Neanidis 2019). The value of sovereign debt and the ability to repay the liabilities are crucial for each economy. This ability seems to be the basis for financial markets' trust in public authorities. According to Steger (2013), the market participants (investors) should trust a given country, or this country will fall into deep trouble soon.

The volume of public debt is one of the most critical factors of fiscal sustainability, which is defined as a situation that excludes financing debt servicing costs exclusively by new borrowing (Fan, Arghyrou 2013, pp. 961-991). In other words, fiscal agents cannot use Ponzi games (see, e.g., Martins-da-Rocha, Vailakis 2012, pp. 455-488; Wigger 2009, pp. 492-499; Minea, Villieu 2010, pp. 709-711), meaning that governments should be able to repay their financial liabilities in the future. If we define sustainability as the absence of default risk, this condition must be met (Neck and Sturm 2008, p. 6). A rapid increase in public debt can affect the lack of fiscal sustainability.

According to the literature, under the idea of the intertemporal budget constraint, public debt should not grow faster than the interest rate (cf. McCallum 1984). Barro (1989) and Kremers (1989) proved that if the economy's growth rate is lower than the interest rate, the public debt to GDP ratio will be limited.

Studies on fiscal sustainability in Central and Eastern European (CEE) countries, including Poland, can be easily found in the literature (see, e.g., Grover, 
Walacik 2019; Uryszek 2019; Uryszek 2016; Mackiewicz-Łyziak 2015). According to these studies, Poland and other CEE countries have severe problems with the fiscal sustainability level. It meets the Maastricht criterion on the level of public debt, but it is insufficient. Poland can generate primary surpluses in the public finance sector, and - at the same time - the level of these surpluses is low and does not allow it to cover the existing debt (even in the long run).

In such a situation, the proper, diversified structure of the sovereign liabilities is crucial for an effective public debt management process (Pascal 2011). Fiscal authorities have to actively search for investors in the domestic and international markets, and foreign investors can play an essential role in this process (see, e.g., Arslanalp, Tsuda 2014). That is why it is so important to investigate how foreign investors react to the Polish public debt management policy and check whether the sovereign debt instruments are attractive for them or not.

\section{Research method and data}

First, we investigated the results of the Polish debt management policy by using the Average Term to Maturity (ATM) and the Average Term to Refixing (ATR) indexes to assess the level of refinancing and interest rate risks, respectively. Then, we analyzed the volume and structure of State Treasury debt in Poland to see if implementing the strategy to reduce Poland's foreign debt is noticeable. We checked the investors' structure carefully to determine what parties are interested in buying Polish Treasury securities. Our method is not a typical approach to examining the reasons for changes in investors' involvement in purchasing assets. Still, we aim to link the response of foreign investors to the risk faced by public authorities directly. The greater the risk for the public sector, the greater the risk for investors. The widespread availability of information on public finance performance in the country means investors are not indifferent to these incentives.

The ATM is defined as the average period (expressed in years) after which the debt is redeemed, and it can be calculated according to formula 1 (see: Ministry of Finance 2018):

$$
A T M=\frac{\sum_{t \in T} t N_{t} I_{0}}{\sum_{t \in T} N_{t} I_{0}}
$$

where:

$t$ - maturity date,

$T$ - set of all maturity dates,

$N_{t}$ - face value paid at time $t$,

$I_{0}$ - current indexation coefficient of inflation-linked instruments' face value (for non-indexed Treasury Securities $I_{0}=1$ ). 
The ATR means the average period, expressed in years, for which the debt servicing costs are set. It can be formally described as in formula 2 (see: Ministry of Finance 2018):

$$
A T R=\frac{\sum_{r \in R} r N Z_{r}+\sum_{t \in T} t N S_{t}+\sum_{j \in J} \frac{1}{12} N I_{j} I_{0}}{\sum_{r \in R} N Z_{r}+\sum_{t \in T} N S_{t}+\sum_{j \in J} N I_{j} I_{0}}
$$

where:

$r \quad$ - payment date of the nearest fixed coupon for floating rate instruments,

$t$ - maturity date for fixed-rate instruments,

$j \quad-$ maturity date for inflation-linked instruments,

$R \quad$ - set of all payment dates of the nearest fixed coupons for floating rate instruments,

$T$ - set of all maturity dates for fixed-rate instruments,

$J \quad$ - set of all maturity dates for inflation-linked instruments,

$N Z_{r}$ - face value of floating rate instruments,

$N S_{t}$ - face value of fixed-rate instruments,

$N I_{j}$ - (non-indexed) face value of inflation-linked instruments,

$I_{0} \quad$ - current indexation coefficient of inflation-linked instruments' face value.

In either case, according to the theory, the higher their values, the lower the refinancing and interest risks remain, respectively. It may be perceived as an incentive to invest in the Polish sovereign debt instruments.

Additionally, the Treasury debt's currency structure was examined to estimate the currency risk of sovereign securities. Checking the refinancing levels, interest rate, and currency risks let us evaluate these instruments' attractiveness and confront it with foreign investors' actual interest in them.

Regarding the Polish sovereign debt's value and structure, we used the monthly data from April 2014 - April 2019, which gave us 61 observations of each variable. The data were derived from the databases of the Polish Ministry of Finance. For comparison purposes, we used the yearly data on the value of the public debt at the General Government and the State Treasury levels in Poland, the European Union, and the Economic Monetary Union.

\section{Empirical results}

Between 2014 and 2019, Poland was characterized by a relatively low public debt value to GDP ratio. The public debt level was much smaller than in the European Union or in the Economic and Monetary Union Countries (see Table 1). We must stress here that the decrease in this ratio was affected by the increase of the GDP rather than reducing the nominal volume of debt (c.f. Figure 1). 
Table 1. Public debt in Poland in the light of the European Union (EU) and the Euro Area (EA) - as a $\%$ of GDP

\begin{tabular}{|l|c|c|c|}
\hline \multicolumn{1}{|c|}{ Year } & EU & EA & Poland \\
\hline 2014 & 87.0 & 92.8 & 50.8 \\
\hline 2015 & 84.9 & 90.9 & 51.3 \\
\hline 2016 & 83.8 & 90.0 & 54.3 \\
\hline 2017 & 82.1 & 87.8 & 50.6 \\
\hline 2018 & 80.4 & 85.8 & 48.8 \\
\hline $\left.2019^{*}\right)$ & 79.3 & 84.1 & 46.0 \\
\hline
\end{tabular}

*) - preliminary data

Source: Eurostat database, Government deficit/surplus, debt and associated data (gov_10dd_edpt1) (accessed: 20 October 2019).

Poland is a fiscally centralized country, where the regional or local sectors' financial autonomy is limited. That is why the General Government debt is mostly created by the Central (State Treasury) level (see Figure 1). Between 2014 and 2019 , sovereign debt amounted to about $96.6 \%$ of the total public debt value.

Figure 1. General Government and Central Government debt in Poland - in PLN billion

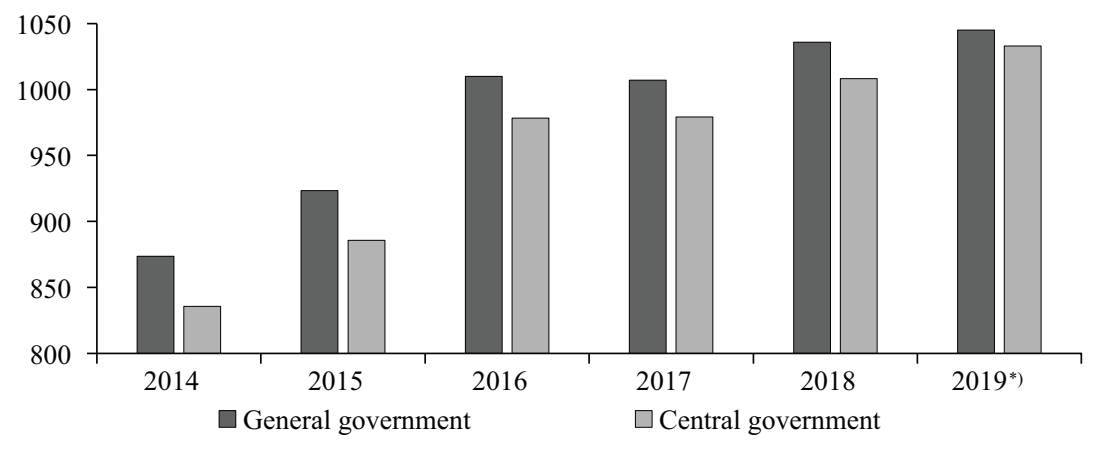

*) - preliminary data

Source: Eurostat database, Government deficit/surplus, debt and associated data (gov_10dd_edpt1) (accessed: 20 October 2019).

During the investigated period, the ATM index values for the foreign State Treasury debt diminished from around seven years and six months in 2014 to about six years in 2019 (see Figure 2), which means that the refinancing risk increased. It is worth noticing that ATM's foreign debt level remained much higher than for the domestic liabilities, but the decrease was much more intense. In contrast, the ATM for domestic investors increased slightly. 
Figure 2. ATM for the Polish sovereign debt (in years)

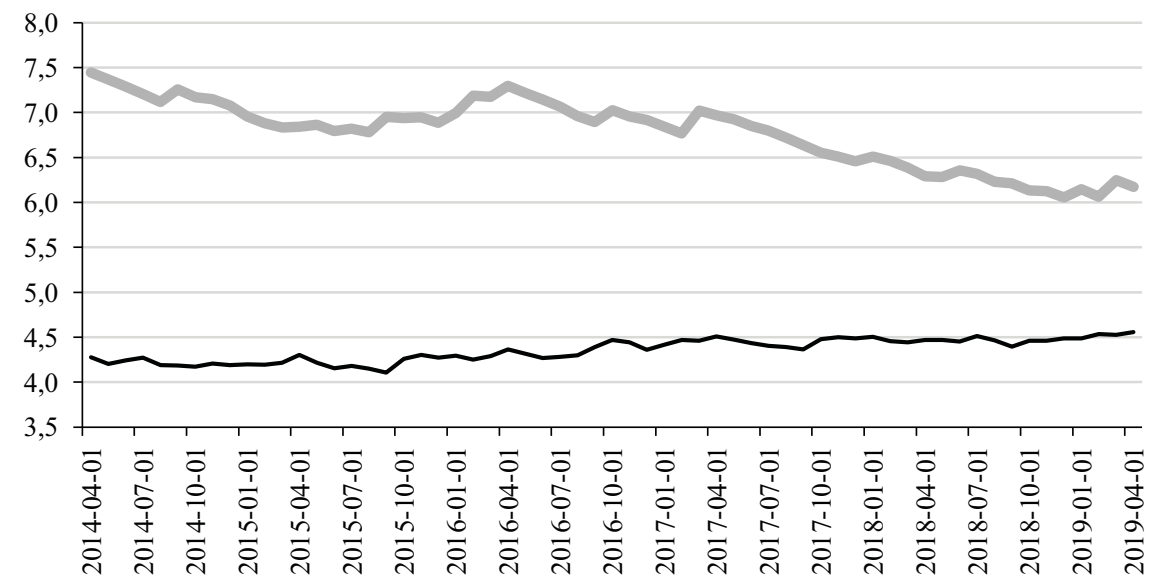

- Residents

Non-residents

Source: own elaboration based on the Ministry of Finance data, https:/www.gov.pl/web/finanse/ szeregiczasowe (file: Zadłużenie Skarbu Państwa) (accessed: 25 October 2019).

The ATR index results are similar to those of the ATM. This index's values diminished from almost six years in April 2014 to less than five years in April 2019 (see Figure 3). However, again, they were much higher than the ATR values for domestic sovereign debt, which is why we may consider the interest rate value to be relatively low.

Figure 3. ATR for the Polish sovereign debt (in years)

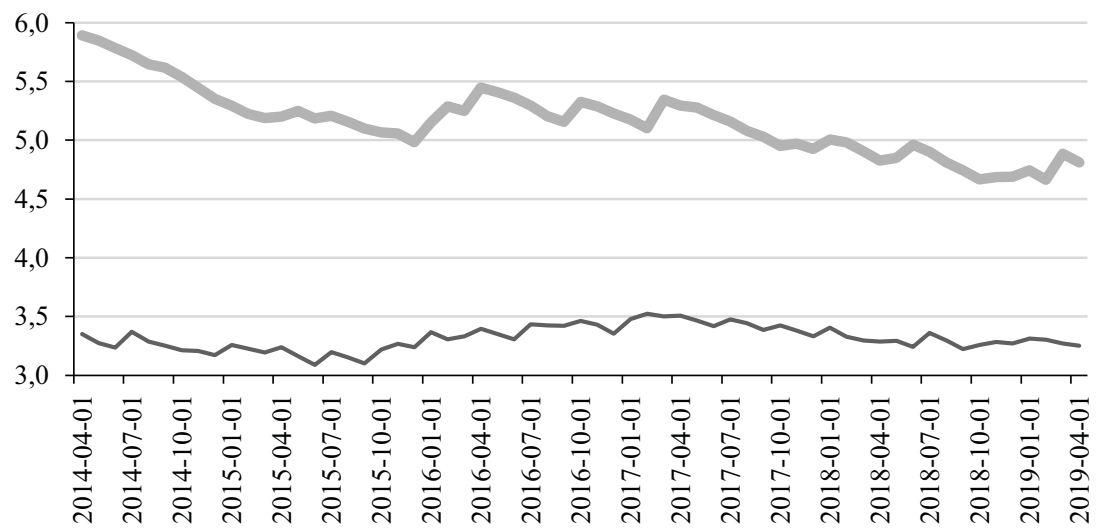

Residents

Non-residents

Source: own elaboration based on the Ministry of Finance data, https://www.gov.pl/web/finanse/ szeregiczasowe (file: Zadłużenie Skarbu Państwa) (accessed: 25 October 2019). 
The ATM and ATR indexes prove that the goals of the Debt Management Strategy are being implemented, but it is necessary to verify the reactions of foreign investors and check whether changes in the ATM and ATR indexes have actually changed the involvement of foreign investors in Polish debt. The rising nominal value of sovereign debt had to be "consumed" by investors interested in lending to the public sector. The share of non-residents diminished from 59\% in April 2014 to 44\% in April 2019. However, their role remains important. The nominal value of debt in the non-resident investors' hands remained relatively stable in this period (437 PLN billion in April 2014 vs. 437 PLN billion in March 2019 and 433 in April 2019) - see Figure 4.

Figure 4. Residents vs. non-residents in the Polish sovereign debt structure (billons of PLN)

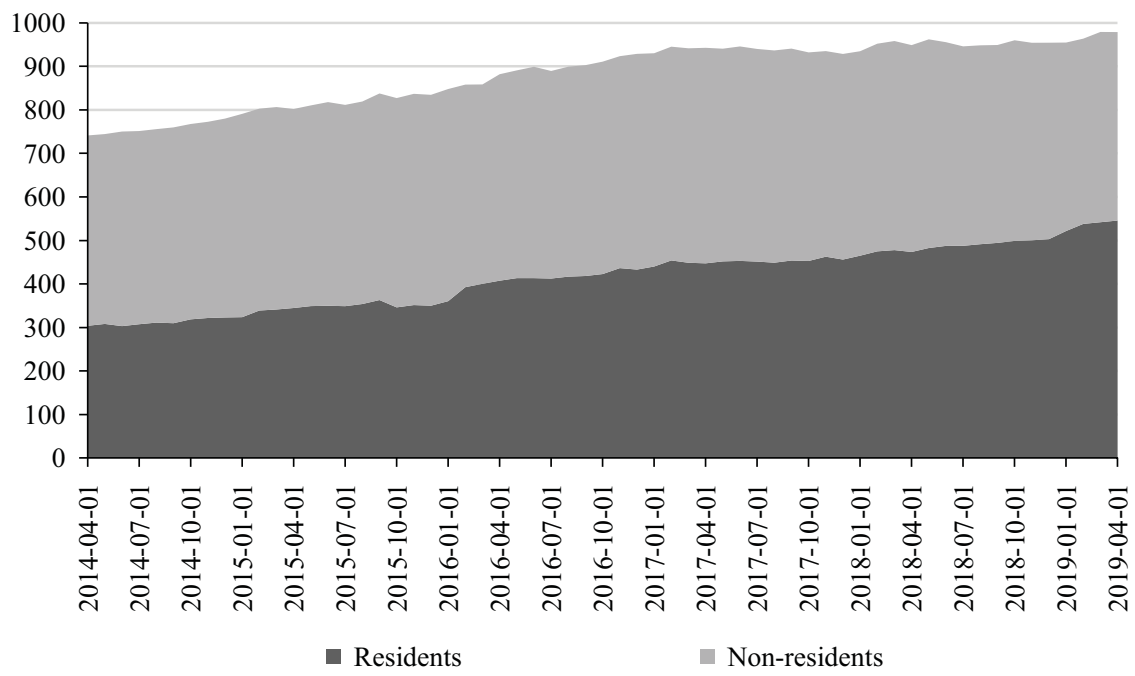

Source: own elaboration based on the Ministry of Finance data, https://www.gov.pl/web/finanse/ szeregiczasowe (file: Zadłużenie Skarbu Państwa) (accessed: 25 October 2019).

Therefore, it seems that the goals of the strategy of debt management have only partly been met. Regardless of the decrease in the ATM and ATR indexes, the relatively low refinancing risk level might have attracted investors to buy the Polish sovereign debt instruments. Their interest in Polish securities may result from a stable macroeconomic situation combined with high public debt ratings and relatively high rates of return. The demand of non-residents for Polish sovereign debt instruments may also be influenced by the activities of central banks and the size and liquidity of the financial market (in particular the public debt market) and its relevant infrastructure (cf. Strategia ... 2018, pp. 20-21).

The currency structure of sovereign debt in Poland has also changed, but it was relatively safe. Around $67 \%$ of the sovereign debt (on average, April 2014 
- April 2019) was denominated in the Polish zloty (PLN). The rest was mostly denominated in strong and stable international currencies (EUR and USD). Only around 3\% (or less) of the sovereign debt (on average) was borrowed in other currencies (see Figure 5).

Figure 5. Currency structure of the Polish sovereign debt

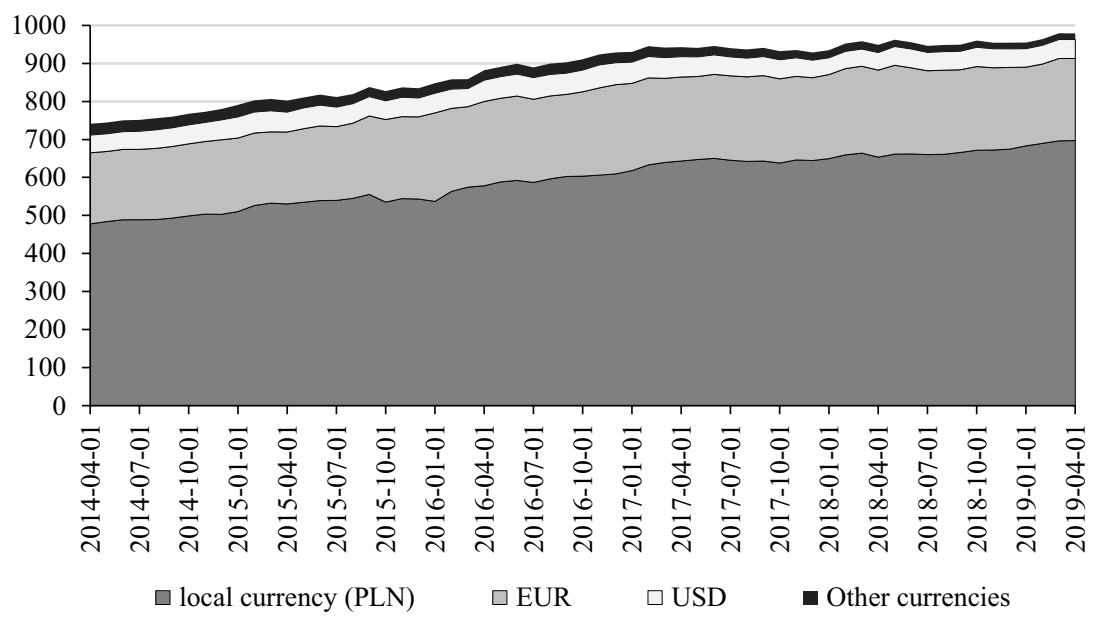

Source: own elaboration based on the Ministry of Finance data, https://www.gov.pl/web/finanse/ szeregiczasowe (file: Zadłużenie Skarbu Państwa) (accessed: 25 October 2019).

Comparing the investors' structure and the currency structure of the sovereign debt provides an interesting insight. In the investigated period, the share of the State Treasury debt denominated in the domestic currency (PLN) was much higher than the percentage of the same debt held by non-residents (foreign investors) - see Table 2. Thus, foreign investors were able to accept the additional currency risk relevant to the exchange rate of the Polish zloty, and they were willing to buy sovereign debt instruments denominated not only in a foreign but also in the local currency. However, their interest in buying securities denominated in PLN was diminishing. In 2014, around 23\% of total Polish sovereign debt was denominated in PLN but owned by foreign investors, while in 2019 , it was less than $14 \%$.

The foreign investors' structure also changed during the investigated period (see: Figure 6). The outflow of investment funds was replaced by other investors, including omnibus accounts. The share of these accounts in the Polish foreign sovereign debt's total value increased from 16\% (and 30.3 billion PLN) in April 2014 to 31\% (and 51.4 billion PLN) in April 2019, respectively. The increase in the number of omnibus accounts was affected by global market changes (cf. Nougayrède 2018) rather than the specific situation of the Polish sovereign debt instruments' market. 
Table 2. Non-residents public debt holders vs. sovereign debt currency structure

\begin{tabular}{|l|c|c|c|}
\hline \multirow{2}{*}{ Year } & \multicolumn{3}{|c|}{ The share of the sovereign debt } \\
\cline { 2 - 4 } & $\begin{array}{c}\text { In the hands } \\
\text { of non-residents } \\
\text { (in \% of total debt) }\end{array}$ & $\begin{array}{c}\text { In PLN } \\
\text { (in \% of total debt) }\end{array}$ & $\begin{array}{c}\text { In other currencies } \\
\text { (in \% of total debt) }\end{array}$ \\
\hline 2014 & 58.6 & 64.5 & 35.5 \\
\hline 2015 & 58.1 & 65.1 & 34.9 \\
\hline 2016 & 53.4 & 65.6 & 34.4 \\
\hline 2017 & 50.9 & 69.4 & 30.6 \\
\hline 2018 & 47.3 & 70.7 & 29.3 \\
\hline $\left.2019^{*}\right)$ & 40.3 & 73.6 & 26.4 \\
\hline
\end{tabular}

*) - preliminary data

Source: own elaboration based on the Ministry of Finance data, https://www.gov.pl/web/finanse/ szeregiczasowe (file: Zadłużenie Skarbu Państwa) (accessed: 25 October 2019).

Figure 6. Types of foreign investors on the Polish sovereign instruments' market

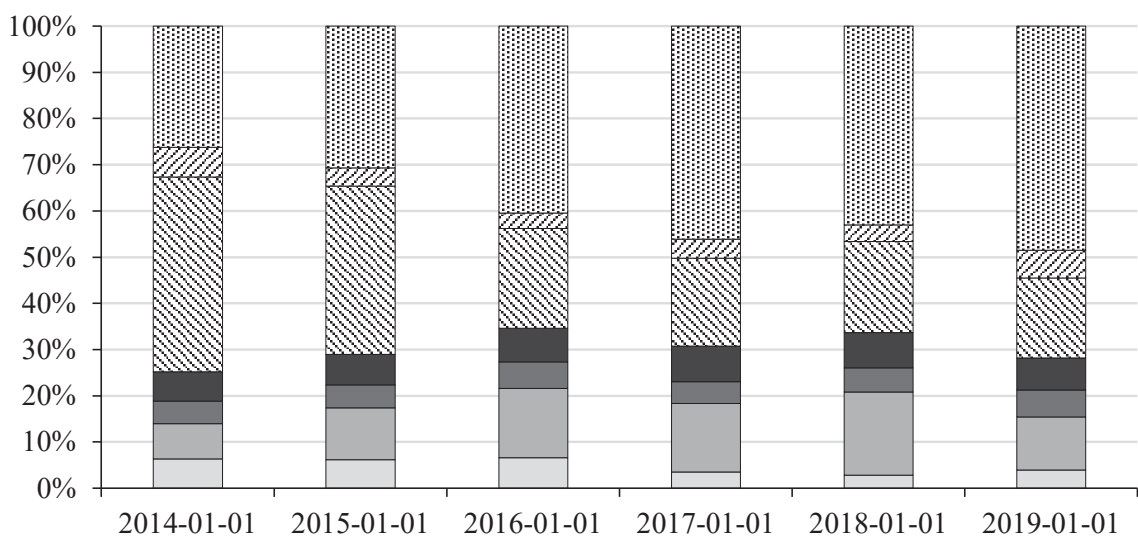

$\square$ Commercial banks

- Pension funds (7) Other*) $\square$ Central banks

बInvestmnent funds $\square$ Insuracnce companies

『non-financial corporations

*) - other: hedging funds, individuals, omnibus accounts, n.e.c. (nowhere else classified) entities. Source: own elaboration based on the Ministry of Finance data, https://www.gov.pl/web/finanse/ struktura-inwestorow (accessed: 29 October 2019).

The geographical structure also changed. Many investments from the USA withdrew, and Japanese investors replaced them (see Figure 7). Moreover, the share of investments from countries usually used by non-European (mostly Asian) investors as a springboard for further activities in the EU member states (the Netherlands, UK) also rose. This may indicate the growing interest of Asian capital in Polish Sovereign assets and weaken American investors' strength. 
Figure 7. Geographical structure of foreign investors on the Polish sovereign market (in billion PLN and \%)
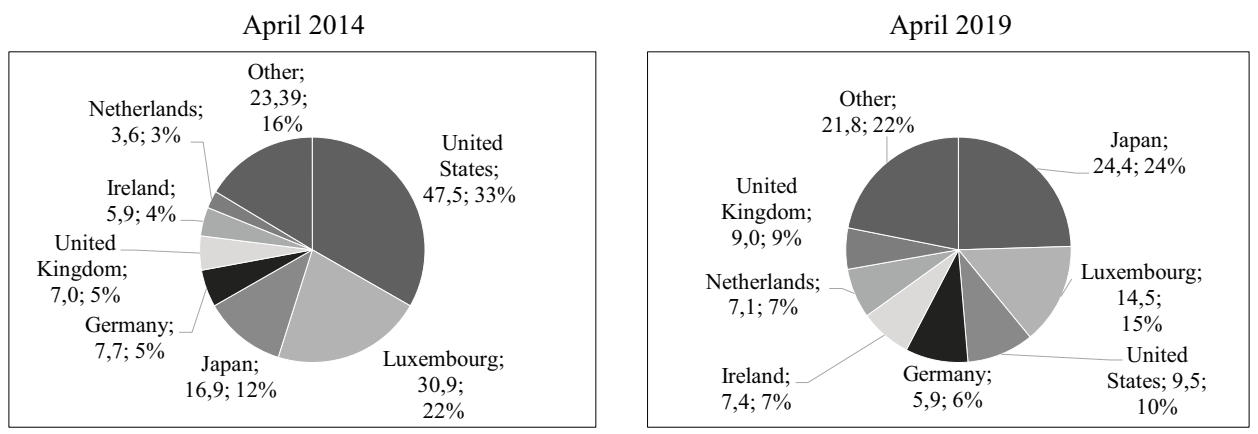

Source: own elaboration based on the Ministry of Finance data, https://www.gov.pl/web/finanse/ struktura-inwestorow (accessed: 29 October 2019).

It is worth mentioning that Polish sovereign debt instruments are in the investors' hands in all continents. It may suggest that, generally, these instruments are relatively interesting for participants of different financial markets.

\section{Conclusions}

Investigations conducted between April 2014 and April 2019 demonstrated that Polish sovereign debt instruments were still interesting for foreign investors, who were attracted by relatively low refinancing and interest rate risks for the debt denominated in foreign currencies. Both of the risks were much lower than the risks for the debt denominated in Polish zloties.

Additionally, a growing share of the debt was denominated in Polish zloties. The rest was denominated in strong and stable international currencies, mainly the EUR and USD. Foreign investors bought sovereign debt instruments denominated not only in a foreign currency but also in the local currency, although their interest in the latter was falling. It seems that their willingness to accept the additional currency risk relevant to the exchange rate of the Polish zloty was weakening.

Debt structure by type of investor and their geographical origin changed during the investigated period. Investment funds withdrew, replaced by other entities, including omnibus accounts. These changes are related to global market shifts rather than the specific situation in Poland. Additionally, many investments from the USA withdrew, and the Japanese investors replaced them.

All in all, we can assume that the public debt management policy led to a slow but stable change in foreign investors' involvement in the Polish debt structure. However, the Polish sovereign securities remain interesting for them. 


\section{Bibliography}

Ahlquist, J.S. (2006). Economic Policy, Institutions, and Capital Flows: Portfolio and Direct Investment Flows in Developing Countries, "International Studies Quarterly", 50(3): 681-704.

Arslanalp, S., Tsuda, T. (2014). Tracking Global Demand for Advanced Economy Sovereign Debt, "IMF Economic Review", 62(3): 430-464.

Barro, R.J. (1989). The Ricardian approach to budget deficits, "Journal of Economic Perspectives", 3(2): 37-54.

Bitzenis, A., Žugić, V. (2014). FDI Motives in the Serbian Manufacturing Sector, "Journal of East-West Business", 20(1): 1-24.

Capasso, S., Neanidis, K. (2019). Domestic or foreign currency? Remittances and the composition of deposits and loans, "Journal of Economic Behavior \& Organization", 160: 168-183.

Cazac, D. (2018). Operational Risk Administration - Essential Component of Public Debt Management Efficiency, "Knowledge Horizons", 10(4): 45-55.

Fan, J., Arghyrou, M.G. (2013). UK Fiscal Policy Sustainability, 1955-2006, “The Manchester School”, 81(6): 961-991.

Garg, R., Dua, P. (2014). Foreign Portfolio Investment Flows to India: Determinants and Analysis, "World Development", 59: 16-28.

Grover, R., Walacik, M. (2019). Property Valuation and Taxation for Fiscal Sustainability - Lessons for Poland, "Real Estate Management \& Valuation", 27(1): 35-48.

Grundke, P. (2004). Integrating Interest Rate Risk in Credit Portfolio Models, "Journal of Risk Finance", 5(2): 6-15.

Hayat, A. (2019). Foreign Direct Investments, Institutional Quality, and Economic Growth, "Journal of International Trade \& Economic Development", 28(5): 561-579.

Ho, H.K., Atkinson, R. (2018). Looking for big 'fry': The Motives and Methods of Middle-Class International Property Investors, "Urban Studies", 55(9): 2040-2056.

Kremers, J.J.M. (1989). US Federal Indebtedness and the Conduct of Fiscal Policy, "Journal of Monetary Economics", 23(2): 219-238.

Mackiewicz-Łyziak, J. (2015). Fiscal Sustainability in CEE Countries - the Case of the Czech Republic, Hungary and Poland, "Equilibrium", 10(2): 53-71.

Martins-da-Rocha, V-.F., Vailakis, Y. (2012). On Ponzi schemes in infinite horizon collateralized economies with default penalties, "Annals of Finance", 8(4): 455-488.

Matsumura, K., Kakinoki, H. (2014). Portfolio Strategy Optimizing Model for Risk Management Utilizing Evolutionary Computation, "Electronics \& Communications in Japan", 97(8): 45-62. 
McCallum, B.T. (1984). Are Bond-financed Deficits Inflationary?: A Ricardian Analysis, "Journal of Political Economy", 92(1): 123-134.

Minea, A., Villieu, P. (2010). Endogenous growth, government debt and budgetary regimes: a corrigendum, "Journal of Macroeconomics", 32(2): 709-711.

Neck, R., Sturm, J-.E. (2008). Sustainability of public debt. Cambridge, MA: Massachusetts Institute of Technology Press.

Nougayrède, D. (2018). Towards a Global Financial Register? The Case for End Investor Transparency in Central Securities Depositories, "Journal of Financial Regulation", 4(2): 276-313.

Pascal, M. (2011). Public Debt Management - Fundamental Component of Public Policy, "Centre for European Studies Working Papers", 3(4): 571-578.

Steger, G. (2013). Redirecting public finance towards a sustainable path, "OECD Journal on Budgeting", 2012(2): 61-67.

Strategia zarządzania dtugiem sektora finansów publicznych w latach 2019-2022 [Public debt management strategy 2019-2022] (2018), Ministry of Finance, Warsaw. https://www.gov.pl/web/finanse/strategie-zarzadzania-dlugiem (accessed: April 2019).

Uryszek, T. (2016). Primary Deficit Indicator, Tax Gap, and Fiscal Sustainability - Evidence from Central and Eastern EU Member States, "FINANSE. Czasopismo Komitetu Nauk o Finansach PAN", 1(9): 103-116.

Uryszek, T. (2019). Can Fiscal Paths Be Sustainable? Evidence from Poland, "Emerging Markets Finance and Trade", https://doi.org/10.1080/154049 6X.2019.1668768

Wigger, B.U. (2009). A note on public debt, tax-exempt bonds, and Ponzi games, "Journal of Macroeconomics", 31(3): 492-499.

\section{Summary}

The article's primary goal is to investigate foreign investors' activity on the Polish primary debt instruments market in light of the public debt management strategy. We wanted to check the scale of investors' response to the authorities' policy in the sovereign debt area. The article consists of five parts. We started with the introduction, followed by a literature review. We then described the research method and data, as well as the empirical discussion. We based our study mostly on the average time to maturity (ATM) and average time to refixing (ATR) indexes. The most important findings, concluding remarks, and policy implications are presented in the last part of the paper. The study's general outcomes show that despite the deterioration of the State Treasury debt instruments' overall characteristics targeted to foreign investors, 
Polish sovereign debt papers remained attractive to buy. It was mostly due to the still relatively low refinancing and interest rate risks for debt denominated in foreign currencies.

Keywords: sovereign debt, foreign investors, Polish Treasury securities, public debt management

JEL: F34, H63

\section{Streszczenie}

Czy skarbowe instrumenty dłużne są nadal atrakcyjne dla inwestorów zagranicznych? Polska - studium przypadku z wykorzystaniem wskaźników ATM i ATR

Głównym celem artykułu jest ocena aktywności inwestorów zagranicznych na polskim, pierwotnym rynku instrumentów dłużnych w świetle strategii zarządzania długiem publicznym. Sprawdzono skalę reakcji inwestorów na politykę władz w obszarze długu państwowego. Artykuł składa się z pięciu części: wprowadzenia, przeglądu literatury, opisu metody badawczej i danych, oraz dyskusji wyników. Najważniejsze ustalenia, uwagi końcowe i implikacje polityczne zostały przedstawione w ostatniej części opracowania. Wyniki badania wskazały, że pomimo pogorszenia się ogólnej charakterystyki instrumentów dłużnych Skarbu Państwa skierowanych do inwestorów zagranicznych, pozostały one atrakcyjne dla nierezydentów. Wynikało to głównie z wciąż stosunkowo niskiego ryzyka refinansowania i stopy procentowej dla długu denominowanego w walutach obcych.

Słowa kluczowe: dług publiczny, inwestorzy zagraniczni, polskie skarbowe papiery wartościowe, zarządzanie długiem publicznym 